Solid Earth Discuss., 3, 431-452, 2011

www.solid-earth-discuss.net/3/431/2011/

3, 431-452, 2011

The thermal structure of Israel

\title{
The thermal structure of Israel
}

\section{E. Shalev ${ }^{1}$, V. Lyakhovsky ${ }^{1}$, Y. Weinstein ${ }^{2}$, and Z. Ben-Avraham ${ }^{3}$}

${ }^{1}$ Geological Survey of Israel, 30 Malkhe Israel, Jerusalem, 95501, Israel

${ }^{2}$ Department of Geography and Environment, Bar-Ilan University, Ramat-Gan, 52900, Israel

${ }^{3}$ Department of Geophysics and Planetary Sciences, Tel-Aviv University, Tel-Aviv 69978, Israel

Received: 13 April 2011 - Accepted: 21 April 2011 - Published: 29 April 2011

Correspondence to: E. Shalev (eyal@gsi.gov.il)

Published by Copernicus Publications on behalf of the European Geosciences Union.

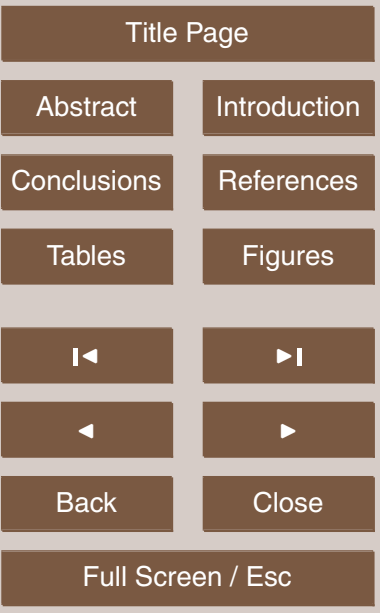

Printer-friendly Version

Interactive Discussion 


\section{Abstract}

Heat flux at the Arabian Shield is a significant component in reconstructing tectonic, seismic, and hydrologic models. In this paper we analyze temperature data from all the available oil and water wells in Israel. We show that the average heat flux in Israel

5 is $40-45 \mathrm{~mW} \mathrm{~m}^{-2}$. A supporting evidence for the low heat flux is the relatively deep seismicity, extending almost to the mantle in the region. A Heat flux anomaly that exists in Northern Israel and Jordan could be attributed to groundwater flow or young magmatic activity ( 100000 years) that is common in this area. Xenoliths that yield relatively steep geothermal gradients could be the result of local heating by magmas or by lithospheric necking and shear heating. The higher Heat flux in Southern Israel and Jordan probably reflects the opening of the Red Sea and the Gulf of Eilat and does not reflect the average value of the Arabian Shield.

\section{Introduction}

Heat flux is a major factor that affects the rheology of the lithosphere, magmatism, and groundwater flow (Ranalli and Rybach, 2005). Different assumptions for the heat flux in Israel have led to different tectonic and seismological models (Al-Zoubi and ten Brink, 2002; Aldersons et al., 2003; Sobolev et al., 2005). The heat flux controls the thickness of the lithosphere, the type of deformation (brittle versus ductile), and the depth of the seismogenic zone (Ranalli, 1995). Sobolev et al. (2005) and Petrunin and

20 Sobolev (2006) presented results of a three-dimensional thermo-mechanical model of a pull-apart basin formed at left stepping segments of an active continental transform fault such as the Dead Sea basin. Adopting the classical scheme of a pull-apart basin formation, they demonstrated that the major parameter controlling the basin structure and deformation pattern beneath the basin is the thickness of the brittle layer. Significant ductile deformation of the lower crust and upper mantle associated with basin growth due to a pull-apart mechanism requires normal or elevated heat flux. The

\section{SED}

3, 431-452, 2011

The thermal structure of Israel

E. Shalev et al.
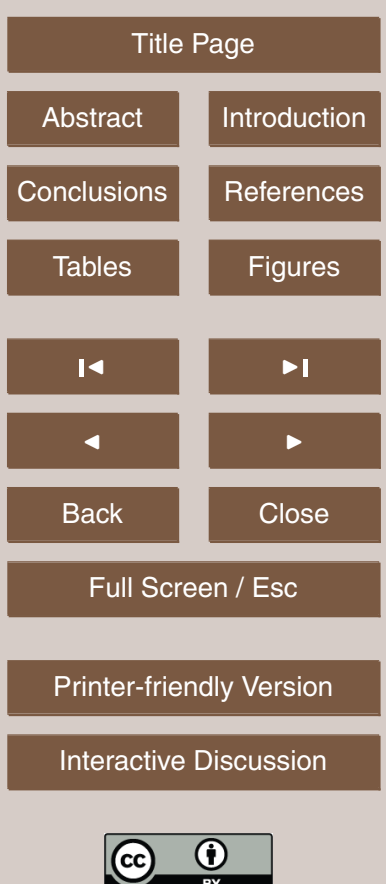
closest fit to the Dead Sea structure have been obtained with the model corresponding to a surface heat flow above $60 \mathrm{~mW} \mathrm{~m}^{-2}$. They also argued that a strong lower crust in a cold lithosphere with heat flow below $50 \mathrm{~mW} \mathrm{~m}^{-2}$ could not allow the opening of a pull-apart such as the Dead Sea basin

5 Recently, Förster et al. (2010) analyzed a set of samples from the uppermost crust down to the lithospheric mantle underneath Jordan and argued that their composition and petrophysical properties support heat flux of $60-65 \mathrm{~mW} \mathrm{~m}^{-2}$. These values are compatible with the average heat flux of $56-66 \mathrm{~mW} \mathrm{~m}^{-2}$ measured in five boreholes at southeastern Jordan (Förster et al., 2007). Thermobarometric calculations, based 10 on lower crustal and lithospheric mantle xenoliths, suggest even significantly steeper geothermal gradients (e.g. McGuire, 1988; McGuire and Bohannon, 1989; Nasir, 1992; Stein et al., 1993; Al-Mishwat and Nasir, 2004), thus higher heat flux $\left(>80 \mathrm{~mW} \mathrm{~m}^{-2}\right)$. The above considerations contradict the general view of the Arabian Shield as an anomalously cold terrain characterized by heat flux values below $\sim 45 \mathrm{~mW} \mathrm{~m}^{-2}$ (Get15 tings and Showail, 1982). Davies and Davies (2010) showed that the heat flux along the Red Sea is very high $\left(>150 \mathrm{~mW} \mathrm{~m}^{-2}\right)$, whereas the heat flux at the Arabian Shield is low $\left(<55 \mathrm{~mW} \mathrm{~m}^{-2}\right)$. Measurements supporting low geothermal heat flux were published by Eckstein (1976) and Eckstein and Simmons (1978), who measured thermal gradients and thermal conductivity in abandoned oil wells and unused water boreholes distributed over Israel. They calculated an average heat flux of $42 \mathrm{~mW} \mathrm{~m}^{-2}$. The mean value of the corrected heat data for the northern part of the Dead Sea basin is $38 \mathrm{~mW} \mathrm{~m}^{-2}$ (Ben-Avraham et al., 1978). Recent re-evaluation of the heat flow data for the Dead Sea basin (Shalev et al., 2007) confirmed these low values. Based on coal rank measurements, Bein and Feinstein (1988) showed that a low heat flux has prevailed in the Dead Sea area since the mid-Miocene period.

Another characteristic of a large part of the Dead Sea fault is its anomalous deep seismicity, extending almost to the mantle (Aldersons et al., 2003; Shamir, 2006). Sixty percent of well-constrained micro-earthquakes $(M L \leq 3.2)$ in the Dead Sea basin for the period 1984-1997 nucleated at depths of 20-32 km. The deep seismic activity

\section{SED}

$3,431-452,2011$

The thermal structure of Israel

E. Shalev et al.

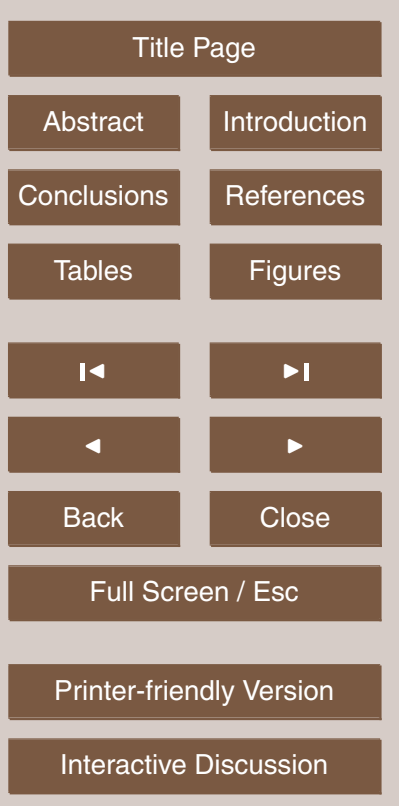


suggests that the lower crust might be cold and brittle and is consistent with a low heat flow of $40 \mathrm{~mW} \mathrm{~m}^{-2}$. This situation is different from that of the San Andreas fault, where the majority of the seismic activity takes place in the upper crust, shallower than $\sim 15 \mathrm{~km}$ depth (e.g., Magistrale, 2002; Rolandone et al., 2004). The slip rate for the San

5 Andreas Fault is several times higher than for the Dead Sea fault. Hence, one might expect a shallower seismogenic zone in Israel. It is probably the difference between the heat fluxes, $60-80 \mathrm{~mW} \mathrm{~m}^{-2}$ in California (e.g., Blackwell and Richards, 2004a, b) and $\sim 40 \mathrm{~mW} \mathrm{~m}^{-2}$ in the Dead Sea, that is responsible for the anomalous deep seismicity along the Dead Sea fault.

10 The purpose of this paper is to reexamine the geothermal heat data collected in Israel for the past 50 years and to determine the average geothermal heat flux in Israel.

\section{Geological setting}

The Arabian Shield is underlain by a continental crust with Phanerozoic sediments overlaying a Late Proterozoic crystalline basement. The basement consists of meta15 morphic and plutonic rocks (mainly granite and diorite compositions). These old rocks (older than 550 Million years) are exposed only in the Eilat area and are covered by thick sedimentary sequences in most of Israel (Fig. 1). The sedimentary cover, which consists mainly of limestone and dolomite and also chalk, sandstone, clay and evaporites, thickens toward the northwest.

20 The tectonic activity along the Red Sea and the Dead Sea transform was accompanied by widespread volcanism since the Oligocene, mainly on its Arabian side. Northern Israel is the only place, where extensive volcanism is also found on the Sinai subplate. Volcanism is intra-plate, alkali-basaltic in nature (e.g. Weinstein et al., 2006), composed mainly of basaltic flows and scoria cones. It mainly occurs at northeastern 25 Israel, with thicknesses between a few tens of meters and more than $800 \mathrm{~m}$. Volcanism in this area is Middle Miocene (17 Ma; Shaliv, 1991) to Late Pleistocene (100 Ka, e.g. Mor, 1993; Weinstein et al., 2009; Shaanan et al., 2010), but younger ages (a few thousand years) were reported for some nearby Syrian basalts (Dubertret, 1954).

\section{SED}

3, 431-452, 2011

The thermal structure of Israel

E. Shalev et al.

Title Page

Abstract

Introduction

Conclusions

References

Tables

Figures

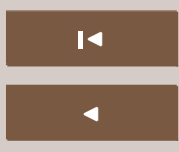

$\Delta$

Back

Close

Full Screen / Esc

Printer-friendly Version

Interactive Discussion 
The tectonic regime of Israel has considerably changed about 15 Million years ago. Faulting produced new plate boundaries in the region including the Dead Sea transform, which separates the Sinai sub-plate and the Arabian plate. The Arabian plate has been displaced by $105 \mathrm{~km}$ northwards relative to the Sinai sub-plate. Several 5 deep pull-apart basins were developed along the Dead Sea transform (Gulf of Eilat, Dead Sea, Sea of Galilee, Hula Valley). These basins are topographically low and their sedimentary cover is very thick. Further south the Arabian plate is also diverging from the African plate while creating and widening the Red Sea. The different tectonic boundaries of the Red Sea Rift (extension) and the Dead Sea Transform (shear) have 10 implications on the heat flux at these fault systems (high at the Red Sea and low at the Dead Sea transform).

\section{Temperature data}

\subsection{Temperature logging}

Logs of continuous temperature measurements were taken in several oil and water 15

wel wells in Israel with the precision of $\pm 0.001^{\circ} \mathrm{C}$. These measurements, when done years after drilling, are considered to be the most reliable data, representing the true formation temperature (the temperature of the geological formation). Often during drilling, cement is used to plug various intervals. Cement generates considerable heat while setting. In fact, temperature logs are regularly taken in order to follow the state of the setting cement. Such logs, performed during and close after drilling, do not represent the true temperature and are ignored in this study.

\subsection{Drill stem test (DST)}

Drill Stem Test is a procedure used to determine the productive capacity, pressure, permeability or extent of an oil or gas reservoir. DST is usually conducted with a

\section{SED}

3, 431-452, 2011

The thermal structure of Israel

E. Shalev et al.
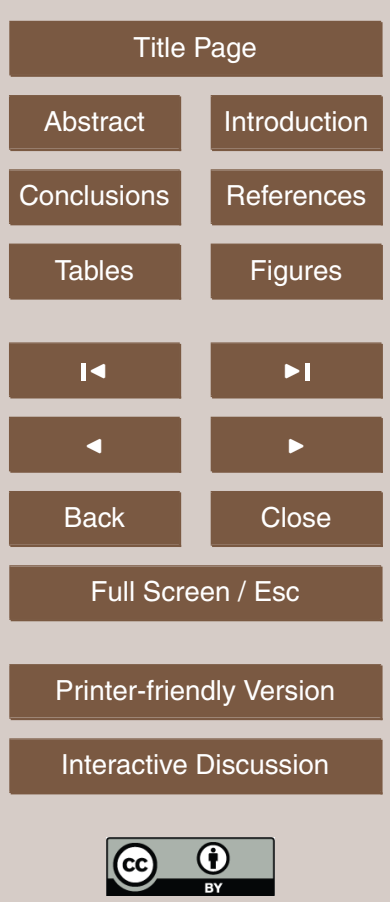
downhole shut-in tool that allows the well to be opened and closed at the bottom of the hole or above the screen with a surface-actuated valve. Often, temperature is also measured during the test. These temperature measurements are considered to be a reliable formation temperature when the test has recovered a fair amount of formation 5 water.

\subsection{Bottom-hole temperature (BHT)}

Bottom-hole temperature is the temperature in the borehole at total depth at the time it is measured. BHT data are routinely obtained during wire-line logging operations and are taken as the maximum recorded temperature during a logging run. The data 10 are typically lower than the true virgin formation rock temperature due to the cooling effect of the drill fluid circulation. If a bottom-hole temperature can be measured several times at a fixed depth while the well is shut in (no drill fluid circulation), it is possible to monitor the well bore temperature as it recovers toward its pre-drilling state, thus permitting extrapolation to virgin rock temperature. However, in the oil wells in Israel, BHT was not measured in every logging operation. In many cases, the temperature from one logging run was often copied later to another log. Therefore, every depth has only one record of measured temperature.

\subsection{Calculated temperature-depth data base}

Förster (2001) showed that in the German basin temperatures perturbed by drilling and mud circulation are higher than the true formation temperature at shallow depth and, below the pivot point, they are lower. In this study, we used Harrison et al. (1983) correction that was developed from North American data, which relates the difference between the formation temperature and BHT to the depth $(Z)$ at which it is measured:

$T_{\text {cor }}=-16.51213476+0.01826842109 \times Z-2.344936959 \times 10^{-6} \times Z^{2}$

\section{SED}

$3,431-452,2011$

The thermal structure of Israel

E. Shalev et al.

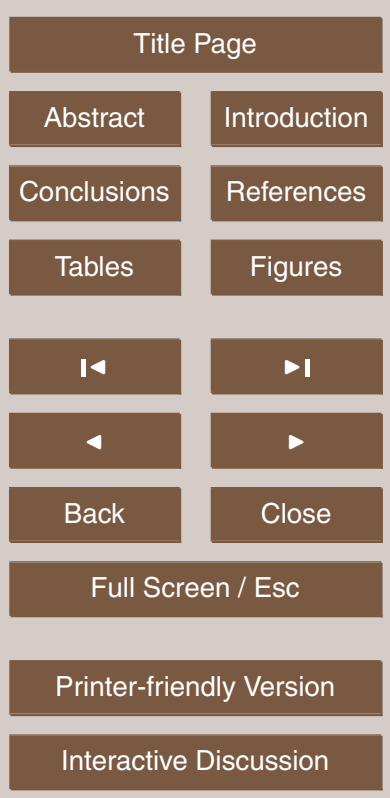


The $T_{\text {cor }}$ values are added to the original BHT values. $Z$ is the depth in meters. The equation is similar to the ones originally proposed by Kehle et al. (1970) and it was applied to produce geothermal maps for North America (Blackwell and Richards, 2004a, b; Blackwell et al., 2006; Tester et al, 2006).

Figure 2 shows that the newly corrected BHT closely fits with temperature logs and DST data. These corrected values are used below for calculating temperature at depth and heat flux maps. In this analysis, only wells that have more than three measurements in different depths are included (221 wells).

\section{Data interpolation}

\subsection{Heat flux map}

A geothermal gradient was calculated for each well with reliable newly generated temperature data. The thermal conductivity was estimated for every section of each well from its lithology (Table 1). The product of the geothermal gradient and the thermal conductivity yields the heat flux (Fig. 3). In some cases the geothermal gradient changes within the well with the lithology, conserving the heat flux. In other cases the temperature gradient was calculated only on one segment of the well with a uniform lithology. In cases where there was a uniform gradient over the entire well, which penetrated mixed lithology of limestone, dolomite, chalk, clay, and marl, an average thermal conductivity of $1.8 \mathrm{~W}\left({ }^{\circ} \mathrm{C} \mathrm{m}\right)^{-1}$ was assumed.

The results show that southeast of the Sea of Galilee and in southern Israel the heat flux exceeds $60 \mathrm{~mW} \mathrm{~m}^{-2}$. Elsewhere, the heat flux is between 35 and $55 \mathrm{~mW} \mathrm{~m}^{-2}$.

\section{SED}

$3,431-452,2011$

\section{The thermal structure} of Israel

\section{E. Shalev et al.}

\section{Title Page}

Abstract

Conclusions

Tables

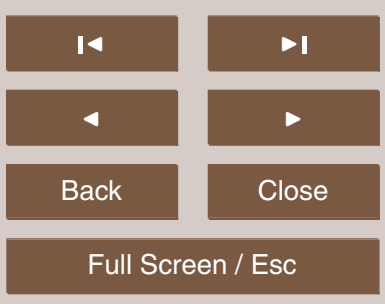

Printer-friendly Version

Interactive Discussion 


\subsection{Maps of temperature at depth}

Following Turcotte and Schubert (1982), we assume that the heat production due to radioactive elements per unit mass decreases exponentially with depth as:

$T(X)=T_{0}+\frac{q_{m} X}{K_{i}}+\frac{\rho_{c} H_{0} h_{r}^{2}}{K_{i}}\left(1-e^{-X / h_{r}}\right)$

5 where $X$ is depth beneath surface, $T_{0}$ is the temperature at the surface, $K_{i}$ is the thermal conductivity of layer $i, q_{m}$ is the mantle heat flux, $H_{0}$ is the radiogenic heat production, $\rho_{\mathrm{c}}$ is the density of the rock, and $h_{r}$ is a length scale. Following Turcotte and Schubert (1982), we use $h_{r}=10 \mathrm{~km}$ and $\rho_{\mathrm{c}} H_{0}=0.0037 \mathrm{~mW} \mathrm{~m}^{-3}$ for the basement. Each borehole was divided into several layers depending on its lithology. Because most of

10 Israel's sedimentary cover consists of chalk, limestone, and dolomite, no radiogenic heat production is assumed for this part.

A depth-temperature profile was fitted to each borehole using Eq. (2). $q_{m}$ was iteratively changed until the surface heat flux was equal to the heat flux in that borehole. Temperature at 4, 6, 8, and $10 \mathrm{~km}$ depth are shown in Figs. 4-7. In each map, the contouring is based on the depth prifile of the boreholes (black circles and is linearly interpolated between the boreholes using ANUDEM - a computer algorithm (Hutchinson, 1989). The reliability of the presented results decreases with depth since only a few measurements were taken at depths greater than $6 \mathrm{~km}$ and none were taken deeper than $6.5 \mathrm{~km}$. Accordingly, the temperature at depths of 6,8 , and $10 \mathrm{~km}$ strongly depend

\section{Discussion}

The average geothermal heat flux throughout Israel is low $\left(40-45 \mathrm{~mW} \mathrm{~m}^{-2}\right)$. Israel is part of the Sinai sub-plate that formed as a result of the break up from the Arabian plate along the left lateral Dead Sea transform and the opening of the Red Sea.

The thermal structure of Israel

3, 431-452, 2011

E. Shalev et al.

\section{Title Page}

Abstract Introduction

Conclusions References

Tables

Figures

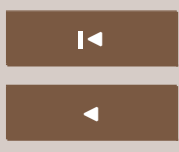

$>$ I

Back

Close

Full Screen / Esc

Printer-friendly Version

Interactive Discussion 
In southern Israel, there are no temperature anomalies down to $10 \mathrm{~km}$ depth. However, the thin sedimentary cover in this region and the high thermal conductivity of the basement results in a relatively high heat flux through southern Israel. Similar values were found by Förster et al. $(2007,2010)$ at this area, which probably represents the 5 effects of the opening of the Red Sea but not the common heat flux in Israel.

At northern Israel, there is a thermal and heat flux anomaly east of the Sea of Galilee. This anomaly could be attributed to groundwater flow. Alternatively, this could be related to crustal heating associated with the young magmatic activity ( 100 000 years) in this area.

10 Upper mantle (lithospheric) and lower crustal xenoliths, including peridotites, pyroxenites and mafic granulites, are often found in Israeli and other Arabian basalts. Thermobarometric calculations, based on mineral equilibria, usually yield relatively high temperatures and steep geothermal gradients (McGuire, 1988; McGuire and Bohannon, 1989; Nasir, 1992; Stein et al., 1993; Al-Mishwat and Nasir, 2004; Gazit, 2005), 15 e.g. $1.015^{\circ} \mathrm{C}$ at $15 \mathrm{kbar}$. This implies a surface heat flux over $80 \mathrm{~mW} \mathrm{~m}^{-2}$ in prominent disagreement with the above. However, the measured high $T$ in xenoliths could as well be the result of local heating at depth by the ascending magmas (Stein et al., 1993; Weinstein et al., 2006) with no impact on heat flux. Moreover, several recent studies suggest that strain localization and development of necking instabilities may occur even in cold lithosphere due to very limited stretching. Benallal and Bigoni, 2004; Regenauer-Lieb and Yuen, 2004; Kaus and Podladchikov, 2006; Regenauer-Lieb et al., 2006; Weinberg et al., 2007; Rosenbaum et al., 2010; Ricard and Froidevaux (1986), Zuber et al. (1986). Accordingly, it could be that a limited extension of the cold Arabian shield lead to, the development of localized lithospheric necking and shear heating required for the high equilibrium temperature documented by the xenoliths. Alternatively, Forster et al. (2010) suggested that the high $P$ - $T$ indicated by lower crustal xenoliths is a "frozen-in" signal, which represent $P-T$ conditions in Pan-African time (Late Proterozoic).

\section{SED}

$3,431-452,2011$

The thermal structure of Israel

E. Shalev et al.

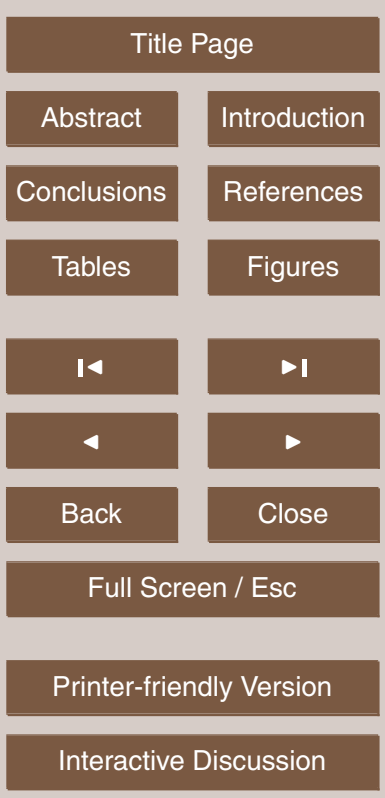


Ben-Avraham and Schubert (2006) proposed a conceptual model of a "drop down" mechanism for the formation of the Dead Sea basin, alternative to the classic pullapart approach. According to their suggestion, propagating faults isolated a block of lithosphere that dropped into the mantle. Ben-Avraham et al. (2010) provided a quan5 titative description of this process by 3-D numerical simulations in a model with a seismogenic crust governed by a continuum damage rheology. Their modeling suggests that pre-existing heavy magmatic body, formed in the crust or upper mantle during previous stages of regional magmatism started dropping down into the upper mantle when strike-slip faults were created. The isostatically non-compensated heavy body 10 detached from the surrounding lithosphere sinking and pulls down the crustal block above it, providing the main mechanism driving formation of the Dead Sea basin. Numerical simulations indicate that the resulting basin is rhomb-shaped, grows by the addition of distinct segments to its edges and created fault geometry mimics the pullapart rhomb-shaped structure, but the mechanism of the basin formation is very dif-

15 ferent. The proposed mechanism accounts for the observed low heat flow and deep seismicity in the Dead Sea.

\section{Conclusions}

Reexamination of temperature data confirms that the common geothermal heat flux throughout Israel is low $\left(40-45 \mathrm{~mW} \mathrm{~m}^{-2}\right)$. The heat flux is higher in southern Israel as a result of the opening of the Red Sea. In northeastern Israel, the relatively high heat flux is attributed to groundwater flow or to the young magmatic activity ( 100000 years) that is common in this area. The steeper geothermal gradients implied by data from xenoliths could be the result of local heating either by the magmatic activity or by lithospheric necking and shear heating.

\section{SED}

3, 431-452, 2011

The thermal structure of Israel

E. Shalev et al.

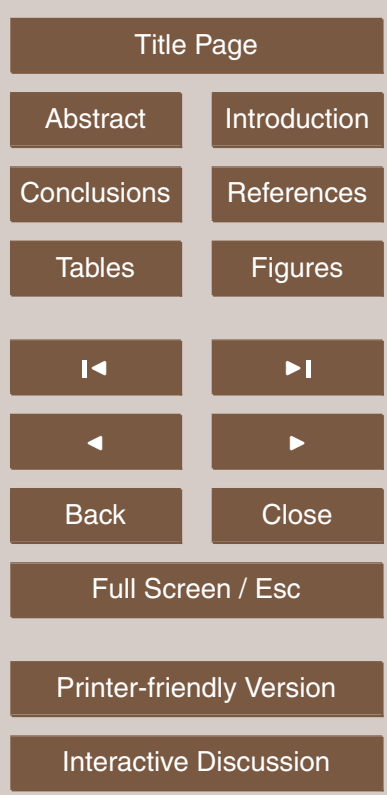


Acknowledgements. We thank the editor Irina Artemieva and an anonymous referee for constructive reviews. V. Lyakhovsky acknowledges support from the Israel Science Foundation (grant ISF 753/08).

\section{References}

5 Aldersons, F., Ben-Avraham, Z., Hofstetter, A., Kissling, E., and Al-Yazjeen, T.: Lower-crustal strength under the Dead Sea basin from local earthquake data and rheological modeling, Earth Planet. Sc. Lett., 214, 129-142, 2003.

Al-Mishwat, A. T. and Nasir, S. J.: Composition of the lower crust of the Arabian Plate: a xenolith perspective, Lithos 72, 45-72, 2004.

Al-Zoubi, A. and ten Brink, U.: Lower crustal flow and the role of shear in basin subsidence: an example from the Dead Sea basin, Earth Planet. Sc. Lett., 199, 67-79, 2002.

Bein, A. and Feinstein, S.: Late Cenozoic thermal gradients in the Dead Sea transform system basins, J. Petrol. Geol., 11, 185-192, 1988.

Ben-Avraham, Z., Hänel, R., and Villinger, H.: Heat flow through the Dead Sea rift, Mar. Geol., 28, 253-269, 1978.

Ben-Avraham, Z. and Schubert, G.: Deep "Drop Down" basin in the southern Dead Sea, Earth Planet. Sci. Lett., 251, 254-263, 2006.

Ben-Avraham, Z., Lyakhovsky, V., and Schubert, G.: Drop-down formation of deep basins along the Dead Sea and other strike-slip fault systems, Geophys. J. Int., 181, 185-197, 2010.

Benallal, A. and Bigoni, D.: Effects of temperature and thermo-mechanical couplings on material instabilities and strain localization of inelastic materials, J. Mech. Phys. Solids., 52, 725-753, doi:10.1016/S0022-5096(03)00118-2, 2004.

Blackwell, D. D. and Richards, M.: Geothermal Map of North America. Amer. Assoc. Petroleum Geologists, Tulsa, Oklahoma, 1 sheet, scale 1:6,500,000, 2004a.

25 Blackwell, D. D. and Richards, M.: Calibration of the AAPG Geothermal Survey of North America BHT Data Base, AAPG Annual Meeting, Dallas, Tx, paper 87616, 2004b.

Blackwell, D. D., Negraru, P. T., and Richards, M.: Assessment of the Enhanced Geothermal System Resource Base of the United States, Natural Resources Research, 15, 283-308, doi:10.1007/s11053-007-9028-7, 2006.

Davies, J. H. and Davies, D. R.: Earth's surface heat flux, Solid Earth, 1, 5-24, 2010.
SED

3, 431-452, 2011

The thermal structure of Israel

E. Shalev et al.

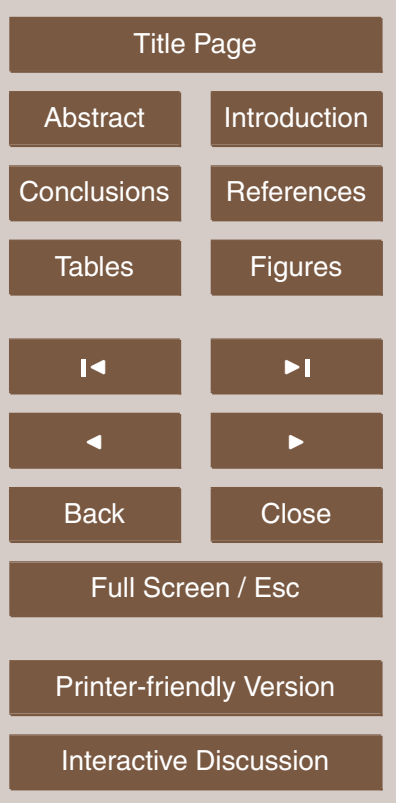


Eckstein, Y.: The measurement and interpretation of terrestrial heat flow in Israel, Report Hydro/3/76, Geological Survey of Israel, 1976.

Eckstein, Y. and Simmons, G.: Measurement and interpretation of terrestrial heat flow in Israel, Geothermics, 6, 117-142, 1978.

5 Förster, A.: Analysis of borehole temperature data in the Northern German Basin: continuous logs versus bottom-hole temperatures, Petrol. Geosci., 7, 241-254, 2001.

Förster, A., Förster, H.-J., Masarweh, R., Masri, A., Tarawneh, K., and DESERT Group: The surface heat flow of the Arabian Shield in Jordan, J. Asian Earth Sci., 30, 271-284, 2007.

Förster, H.-J., Förster, A., Oberhänsli, R., and Stromeyer, D.: Lithospheric composition and thermal structure of the Arabian Shield in Jordan, Tectonophysics, 481, 29-37, 2010.

Gazit, O.: Mafic granulite xenoliths from Qarnei Hittin and the evolution of the lower crust beneath northern Israel, Isr. Geol. Surv. Rep., 67 pp., 2005. (in Hebrew; Engl. Abstr.)

Gettings, M. E. and Showail, A.: Heat-flow measurements at shot points along the 1978 Saudi Arabian deep-refraction line, Part I: Results of measurements, Saudi Arabia Deputy Min. for

15 Mineral Res., Open File Report USGS-OF-02-39. 98 pp., 1982.

Harrison, W. E., Luza, K. V., Prater, M. L., and Chueng, P. K.: Geothermal resource assessment of Oklahoma, Special Publication 83-1, Okla, Geological Survey, 1983.

Hutchinson, M. F.: A new procedure for gridding elevation and stream line data with automatic removal of spurious pits, J. Hydrol., 106, 211-232, 1989.

20 Kaus, B. J. P. and Podladchikov, Y. Y.: Initiation of localized shear zonesin viscoelstoplastic rocks, J. Geophys. Res., 111, B04412, doi:10.1029/2005JB003652, 2006.

Magistrale, $\mathrm{H}$.: Relative contributions of crustal temperature and composition to controlling the depths of earthquakes in southern California, Geophys. Res. Lett., 29(10), 1447 pp., 2002.

Maurath, G.: Thermal constraints on tectonic processes along the Jordan-Dead Sea Transform,

$25 \mathrm{PhD}$ dissertation submitted to Kent State University, 1989.

McGuire, A. V.: Petrology of mantle xenoliths from Harrat al Kishb: the mantle beneath western Saudi Arabia, J. Petrol., 29, 73-92, 1988.

McGuire, A. V. and Bohannon, R. G.: Timing of mantle upwelling: evidence for a passive origin of the Red Sea rift, J. Geophys. Res., 94B, 1677-1682, 1989.

30 Mor, D.: A time-table for the Levant volcanic province, according to K-Ar dating in the Golan Heights, Israel, J. Afr. Earth Sci., 16(3), 223-234, 1993.

Nasir, S.: The lithosphere beneath the northwestern part of the Arabian plate (Jordan): evidence from xenoliths and geophysics, Tectonophysics, 201, 357-370, 1992.

SED

3, 431-452, 2011

The thermal structure of Israel

E. Shalev et al.

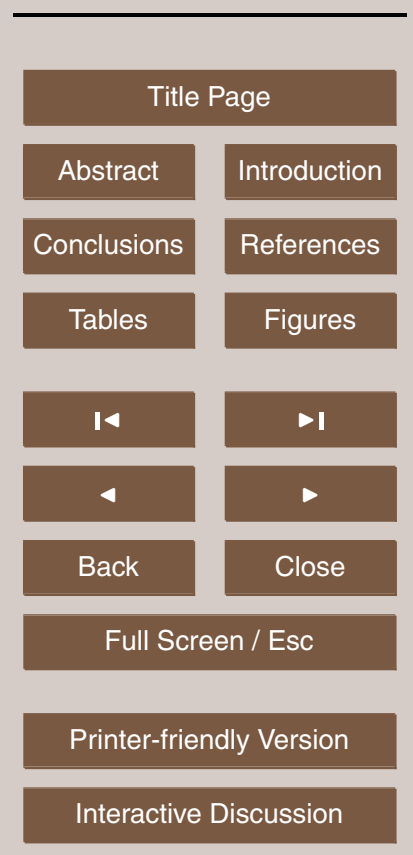


Petrunin, A. and Sobolev, S. V.: What controls thickness of sediments and lithospheric deformation at a pull-apart basin?, Geology, 34, 389-92, 2006.

Ranalli, G.: Rheology of the Earth, 2 Edn. Chapman and Hall, London, 436 pp., 1995.

Ranalli, G. and Rybach, L.: Heat flow, heat transfer and lithosphere rheology in geothermal 5 areas: features and examples, J. Volcanol. Geoth. Res., 148, 3-19, 2005.

Regenauer-Lieb, K. and Yuen, D.: Positive feedback of interacting ductile faults from coupling of equation of state, rheology and thermal-mechanics, Phys. Earth Planet. Int., 142, 113-135, doi:10.1016/j.pepi.2004.01.003, 2004.

Regenauer-Lieb, K., Weinberg, R. F., and Rosenbaum, G.: The effect of energy feedback on continental strength, Nature, 442, 67-70, 2006.

Ricard, Y. and Froidevaux, C.: Stretching instabilities and lithospheric boudinage, J. Geophys. Res., 91(B8), 8314-8324, 1986.

Rolandone, F., Bürgmann, R., and Nadeau, R. M.: The evolution of the seismic-aseismic transition during the earthquake cycle: Constraints from the time-dependent depth distribution of aftershocks, Geophys. Res. Lett., 31, L23610, doi:10.1029/2004GL021379, 2004.

Rosenbaum, G., Regenauer-Lieb, K., and Weinberg, R. F.: Interaction between mantle and crustal detachments: A nonlinear system controlling lithospheric extension, J. Geophys. Res., 115(B11412), doi:10.1029/2009JB006696, 2010.

Rybakov, M. and Segev, A.: Top of the crystalline basement in the Levant, Geochem. Geophys. Geosyst., 5, 8 pp., doi:10.1029/2004GC000690, 2004.

Segev, A., Rybakov, M., Lyakhovsky, V., Hofstetter, A., Tibor, G., Goldshmidt, V., and Ben Avraham, Z.: The structure, isostasy and gravity field of the Levant continental margin and the southeast Mediterranean area, Tectonophysics 425, 137-157, 2006.

Shaanan, U., Porat, N., Navon, O., Weinberger, R., Calvert, A., Weinstein, Y.: OSL dating of a Pleistocene maar: Birket Ram, the Golan heights, J. Volcanol. Geoth. Res., 201, 397-403, doi:10.1016/j.jvolgeores.2010.06.007, 2011.

Shaliv, G.: Stages in the tectonic and volcanic history of the Neogene basin in the Lower Galilee and the Valleys, Geological Survey of Israel Report GSI/11/91, 94 pp., 1991. (in Hebrew)

Shamir, G.: The active structure of the Dead Sea Depression, in: New frontiers in Dead Sea paleoenvironmental research, edited by: Enzel, Y., Agnon, A., and Stein, M., Geological Society of America Special Paper, 401, 15-32, 2006.

Sobolev, S. V., Petrunin, A., Garfunkel, Z., and Babeyko, A. Y.: Thermo-mechanical model of the Dead Sea Transform, Earth Planet. Sc. Lett., 238, 78-95, 2005.

The thermal structure of Israel

E. Shalev et al.

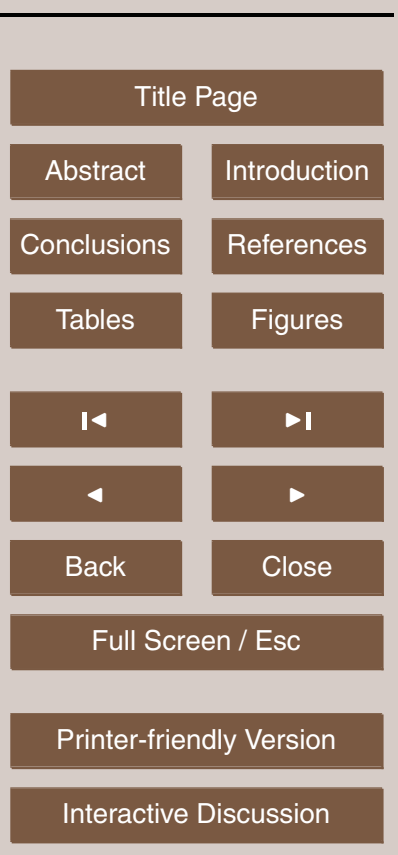


Stein, M., Garfunkel, Z., and Jagoutz., E.: Chronothermometry of peridotitic and pyroxenitic xenoliths: implications for the thermal evolution of the Arabian lithosphere, Geochim. Cosmochim. Ac., 57, 1325-1337, 1993.

Turcotte D. L. and Schubert, G.: Geodynamics: Application of continuum physics to geological problems, 450 pp., John Wiley, New York, 1982.

Weinberg, R. F., Regenauer-Lieb, K., and Rosenbaum, G.: Mantle detachment and the breakup of cold continental crust, Geology, 35(11), 1035-1038, doi:10.1130/G23918A.1, 2007.

Weinstein, Y., Navon, O., Altherr, R., and Stein, M.: The role of fluids and of lithospheric heterogeneity in the generation of alkali basaltic suites from northwestern Arabia, J. Petrol., 47, 1017-1050, 2006.

Weinstein, Y., Weinberger, R., and Shaanan, U.: Magma and water - explosive and collapse structures in the northern Golan, Israel Geological Society Meeting, Kfar Blum, 2009.

Zuber, M., Parmentier, E., and Fletcher, R.: Extension of continental lithosphere: a model for two scales of Basin and Range deformation, J. Geophys. Res., 91(B5), 4826-4838, 1986.

\section{SED}

$3,431-452,2011$

The thermal structure of Israel

E. Shalev et al.

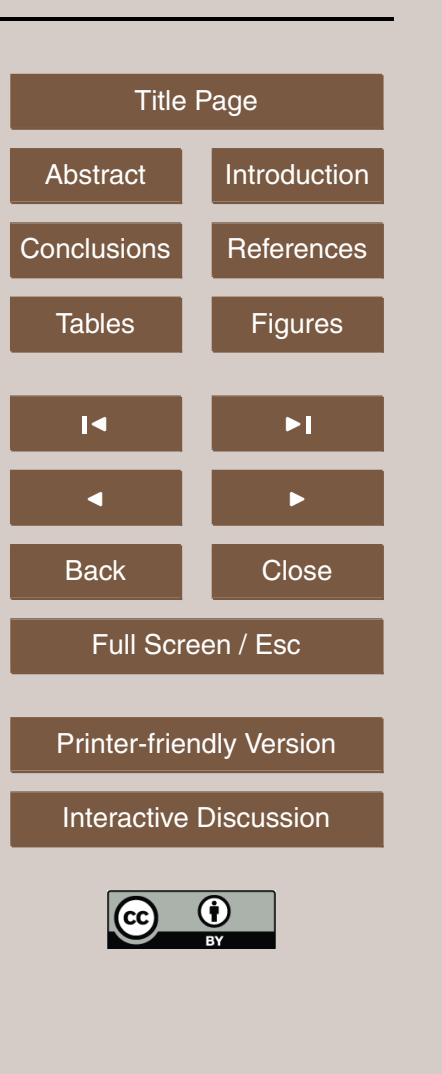


3, 431-452, 2011

The thermal structure of Israel

Table 1. Thermal conductivities of different rocks (data from Eckstein and Simmons, 1978 and Maurath, 1989).

\begin{tabular}{lc}
\hline Rock type & Thermal conductivity $\left(\mathrm{W}\left({ }^{\circ} \mathrm{C} \mathrm{m}\right)^{-1}\right)$ \\
\hline Limestone & 2.1 \\
Dolomite & 3.5 \\
Chalk and Marl & 1.3 \\
Clay and Shales & 1.2 \\
Sandstone & 2.1 \\
Salt & 3.2 \\
Basalt & 1.7 \\
Granite (basement) & 2.7 \\
\hline
\end{tabular}

Title Page

\begin{tabular}{|c|c|}
\hline Abstract & Introduction \\
\hline Conclusions & References \\
\hline Tables & Figures \\
\hline I4 & $\bullet$ \\
\hline 4 & $\triangleright$ \\
\hline Back & Close \\
\hline Full Screen / Esc \\
\hline
\end{tabular}

Printer-friendly Version

Interactive Discussion 


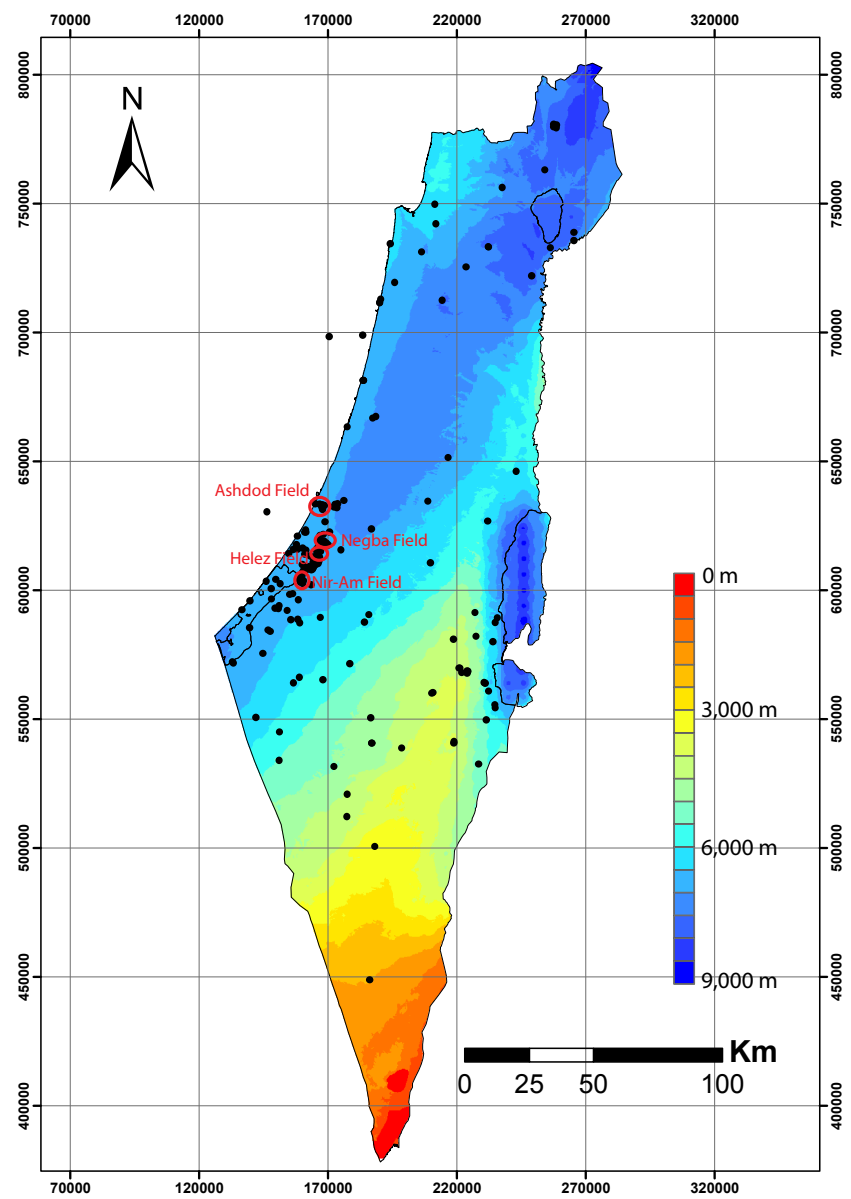

SED

3, 431-452, 2011

The thermal structure of Israel

E. Shalev et al.

Title Page

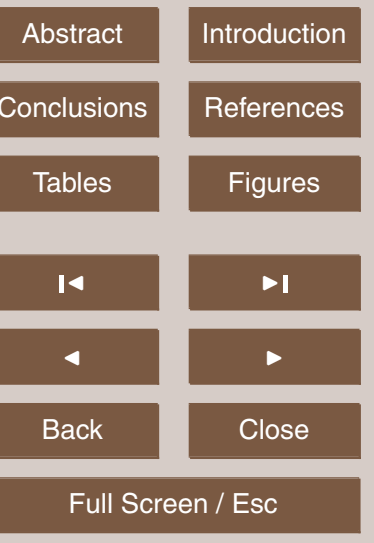

Printer-friendly Version

Interactive Discussion

Fig. 1. The depth of the crystalline basement from the surface (after Rybakov and Segev, 2004 and Segev et al., 2006). This depth represents the sediment thickness. In southern Israel the basement is exposed. 

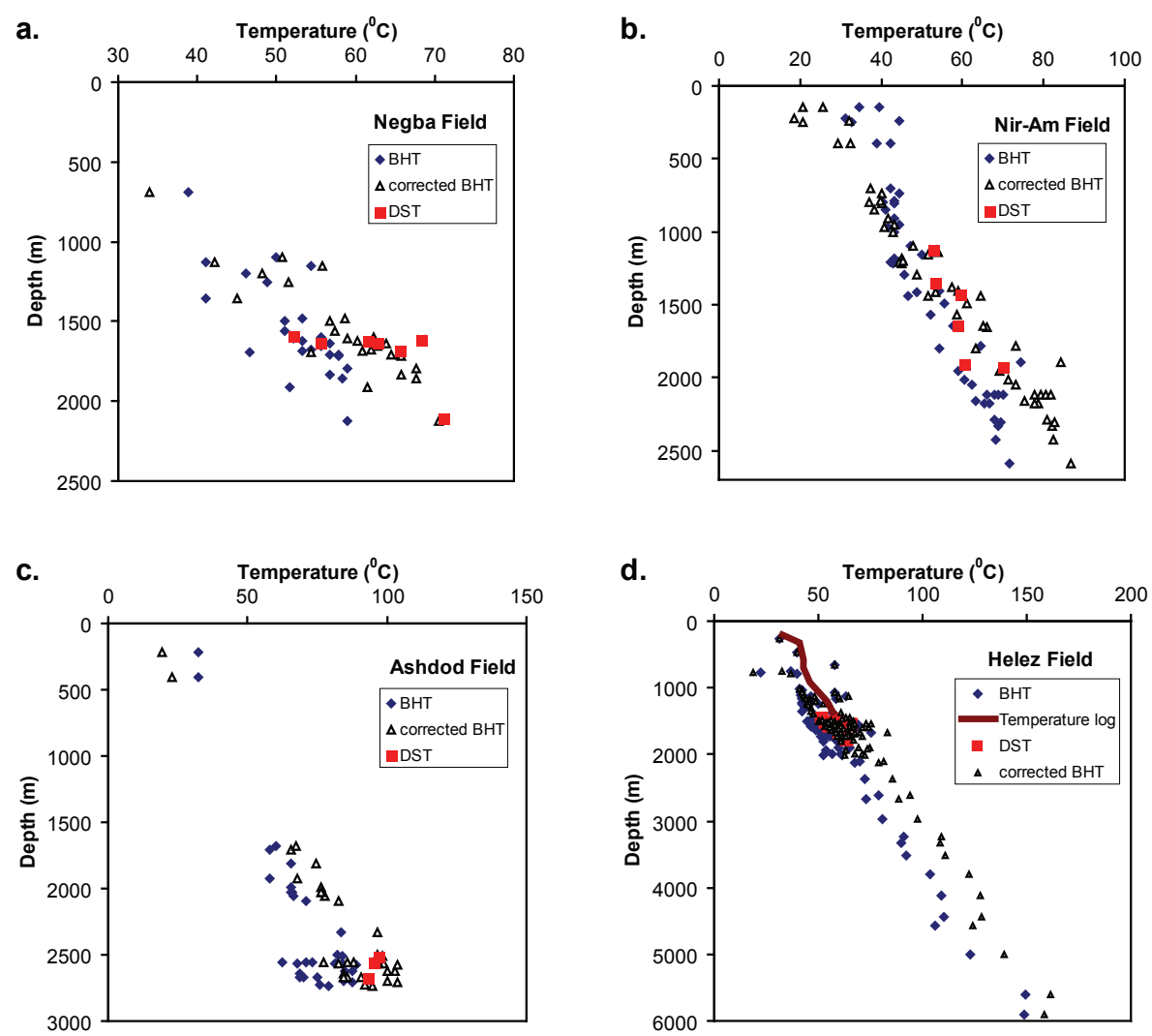

d.

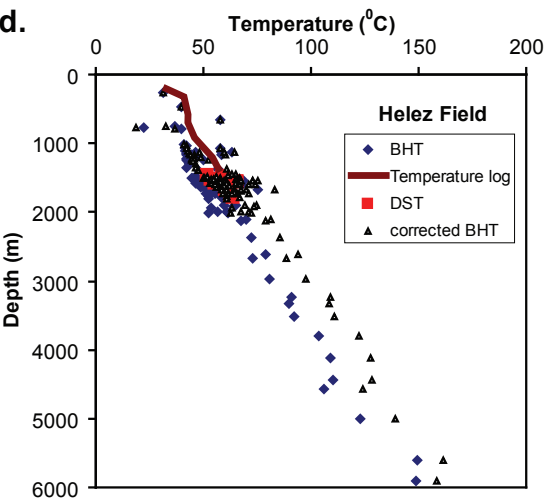

SED

3, 431-452, 2011

The thermal structure of Israel

E. Shalev et al.
Title Page

\begin{tabular}{c|c}
\hline Abstract & Introduction \\
\hline Conclusions & References \\
\hline Tables & Figures \\
\hline I4 & $\triangleright$ I \\
\hline 4 & $\triangleright$ \\
\hline Back & Close \\
\hline Full Screen / Esc
\end{tabular}

Printer-friendly Version

Interactive Discussion temperature and temperature logs in (a) Negba, (b) Nir-Am, (c) Ashdod, and (d) Helez fields. 


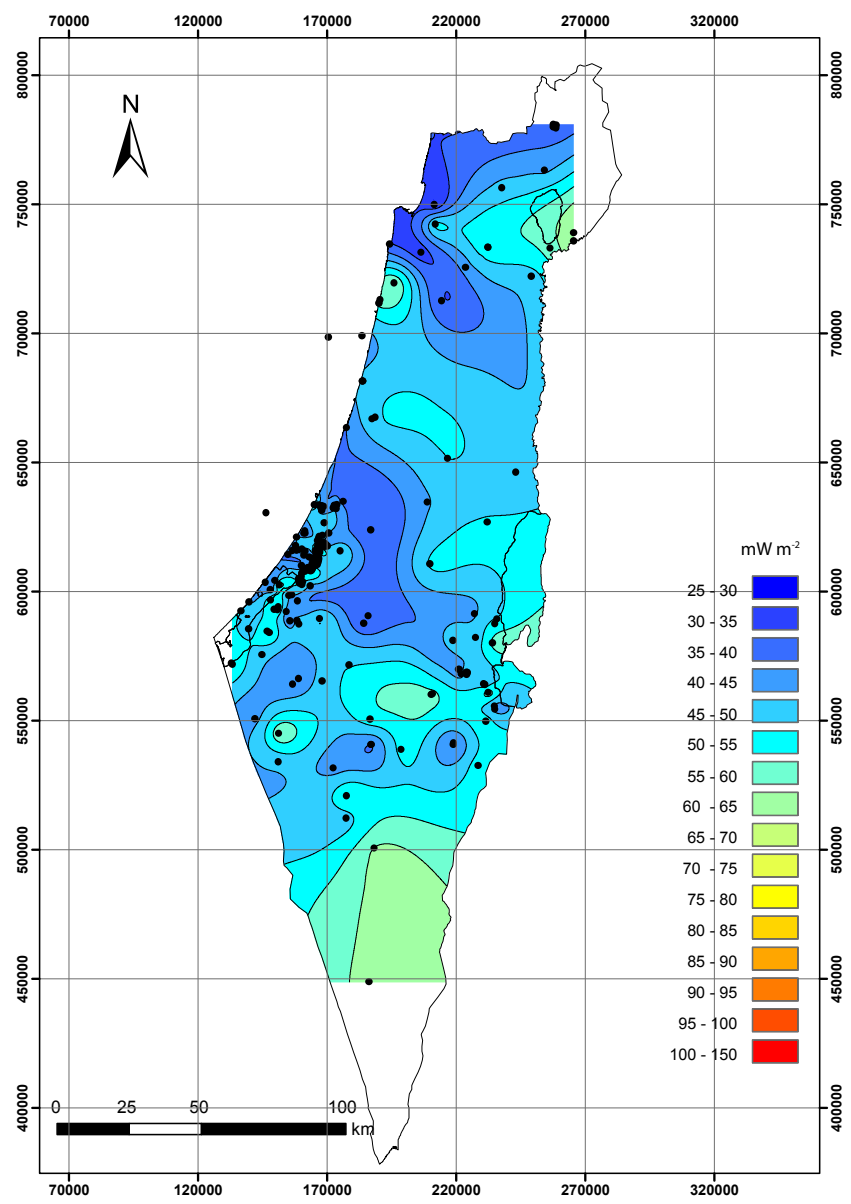

SED

$3,431-452,2011$

The thermal structure of Israel

E. Shalev et al.

Title Page

\section{Abstract}

Conclusions

Tables

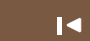

4

Back

Introduction

References

Figures

$\rightarrow$

$>$

Close

Full Screen / Esc

Printer-friendly Version

Interactive Discussion

Fig. 3. Calculated geothermal heat flux in Israel from borehole temperature measurements. South east of the Sea of Galilee and in southern Israel the heat flux is relatively high. Black circles represent the boreholes used for the calculation and interpolation. 


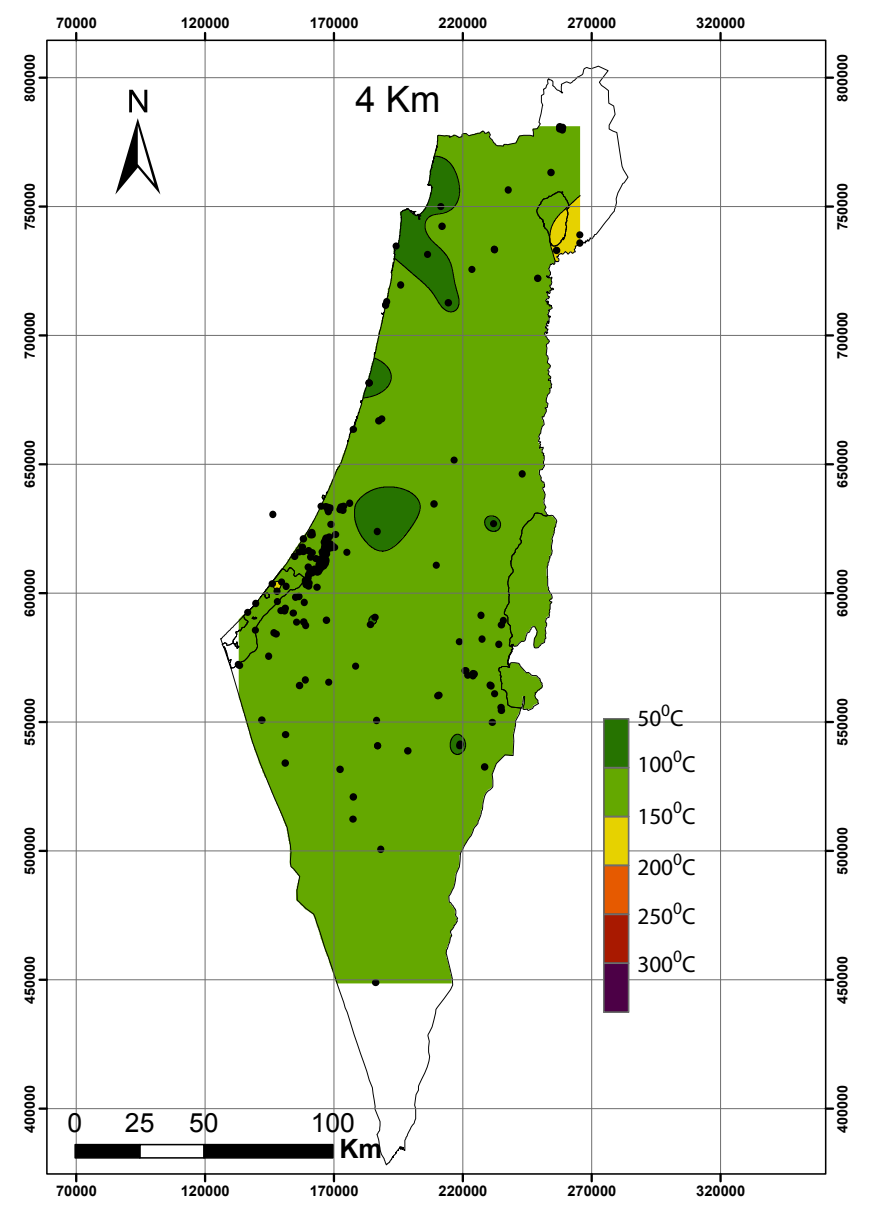

SED

3, 431-452, 2011

The thermal structure of Israel

E. Shalev et al.

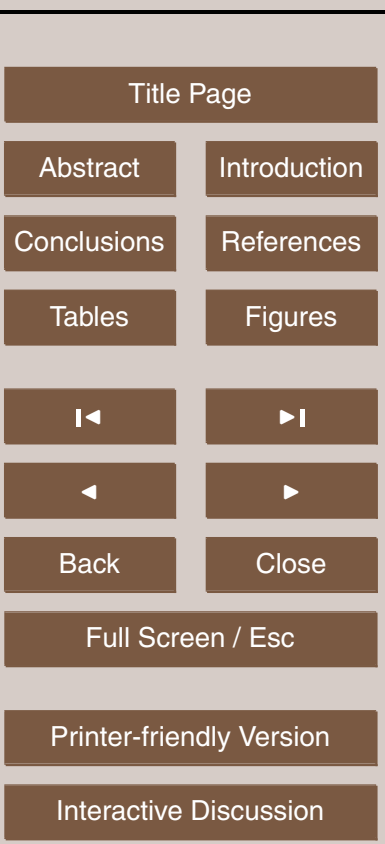

Fig. 4. Average temperature at $4 \mathrm{~km}$.

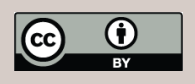




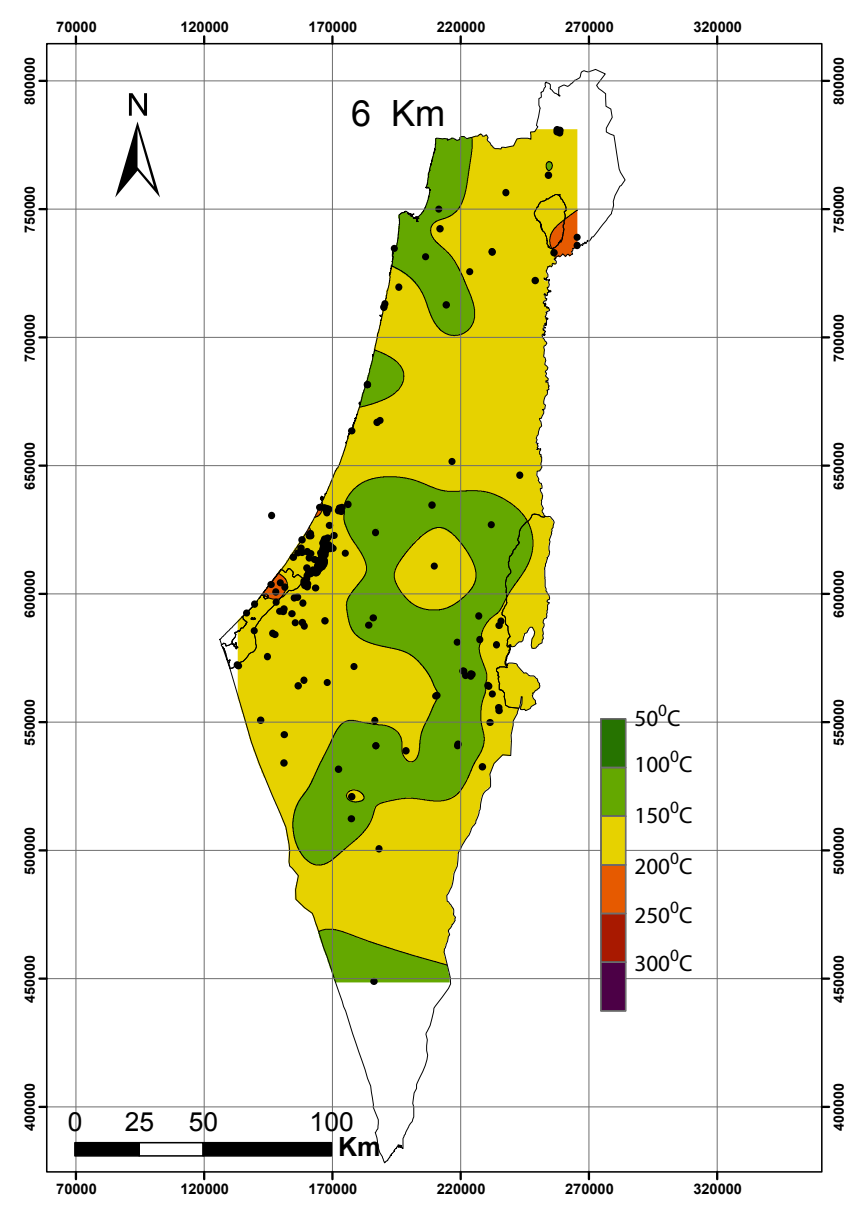

SED

3, 431-452, 2011

The thermal structure of Israel

E. Shalev et al.

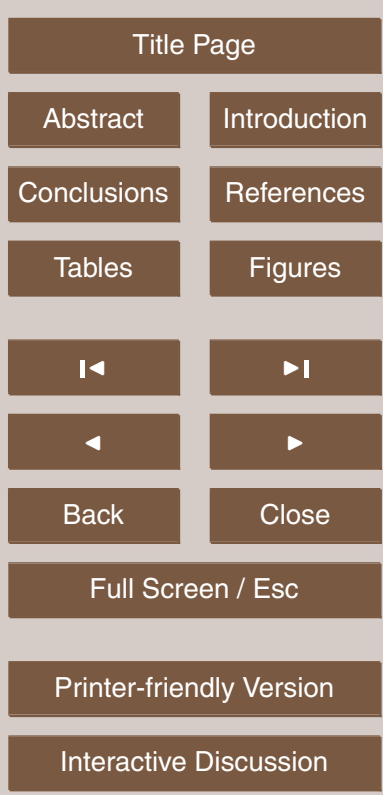

Fig. 5. Average temperature at $6 \mathrm{~km}$.

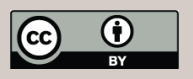




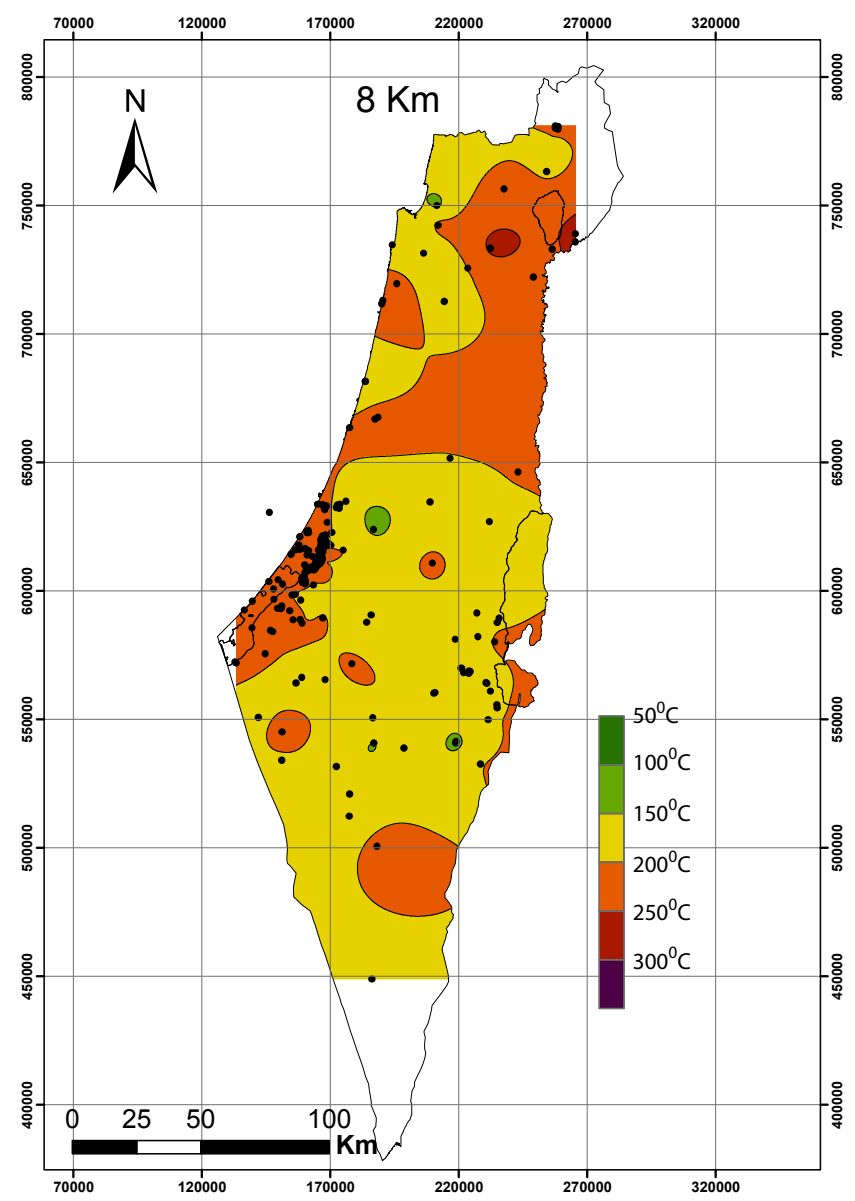

SED

3, 431-452, 2011

The thermal structure of Israel

E. Shalev et al.

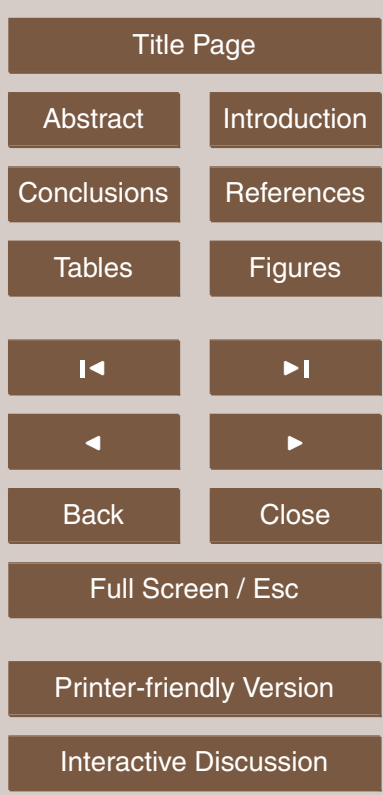

Fig. 6. Average temperature at $8 \mathrm{~km}$. 


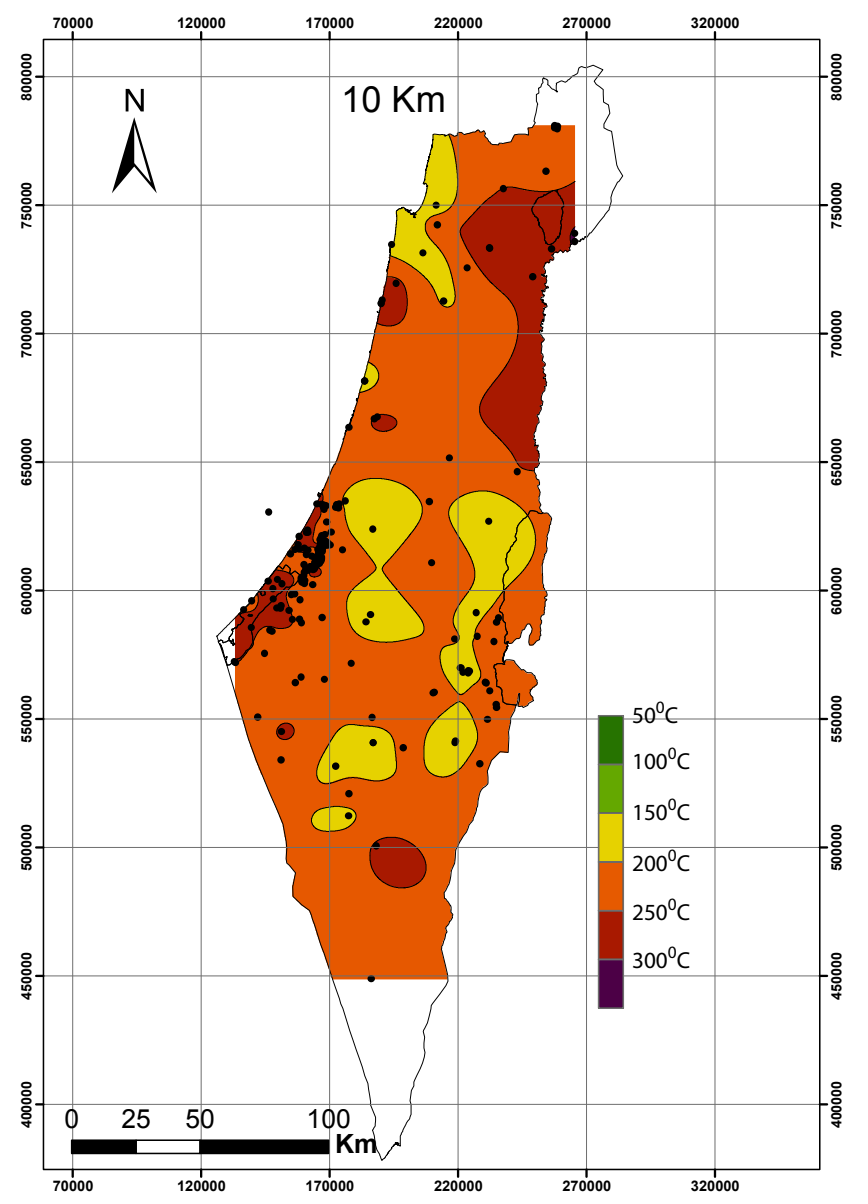

SED

3, 431-452, 2011

The thermal structure of Israel

E. Shalev et al.

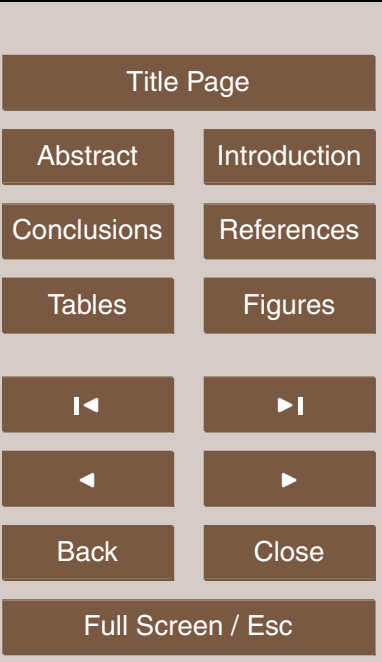

Printer-friendly Version

Interactive Discussion

Fig. 7. Average temperature at $10 \mathrm{~km}$.

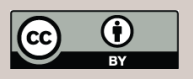

